\title{
Süryanca Liturjik Bir Elyazmasının Süsleme Özellikleri Üzerine İnceleme
}

\author{
A Study on The Ornamental Properties of a Syrian Liturgic Manuscript \\ Betül Coșkun Çelik \\ Dr. Öğr. Üyesi, Bitlis Eren Üniversitesi Güzel Sanatlar Fakültesi Geleneksel Türk Sanatları Bölümü \\ email: bccelik@beu.edu.tr DORCID ID: https://orcid.org/0000-0002-6242-3485
}

Atıf (APA 6)/To cite this article

Coşkun Çelik, B. (2019). Süryanca litürjik bir elyazmasının süsleme özellikleri üzerine inceleme. Atatürk Üniversitesi Güzel Sanatlar Enstitüsü Dergisi, 43, 150-159. doi: https://doi.org/10.32547/ataunigsed.588766

Makale Gönderim Tarihi/Received: 08/07/2019

Makale Kabul tarihi/Accepted: 06/10/2019

Makale Yayın Tarihi/Published: 26/10/2019

Research Article/Araștırma Makalesi

\section{$\ddot{\mathbf{O z}}$}

Mardin il sınırları içinde, Güneydoğu Anadolu Bölgesinin Dicle bölümünde yer alan Midyat şehri; kilise ve manastırların bulunduğu kadim șehirlerdendir. Calıșma konusu, Midyat'ta yer alan Mor Barsavmo Kilisesi arşivine BMCM-00020 numarası ile kayıtlı, yaklaşık 1800'lü yıllara tarihlendirilen Süryanca serto hatla yazılmıș el yazmasının süsleme açısından incelenmesini kapsamaktadır. Hagiografik eserlerde görüleceği üzere, bu Fanqito'da da, aziz ve azizelerin mucizelerinin anlatıldığı, şiir ve ilahilerinin yer aldığı bir kitaptır. Bu eser, Tigrit Metropoliti Aziz Mor Dodo'ya adanmış bir dua ve ilahi kitabıdır.

Calışmada öncelikle kısaca Mor Barsavmo Kilisesi hakkında bilgiler verilmiş, metod ve yöntemler açıklanmıştır. Ardından, araștırmanın bulguları 1șı̆̆ında, Süryanca kaleme alınmıș (yazılmıș) el yazmasının süslemeli sayfaları tek tek incelenmiș, her birinin ayrıntılı çizimleri yapılmış ve süslemelerin bulunduğu varakların metin içeriklerinin özetle nelerden bahsettiğine değinilmiştir. El yazmasında yer alan birbirini takip eden geometrik bezeme kompozisyonlar, ikili, üçlü, dörtlü zencerekler, örgüler, özellikle geçmelerden oluşmaktadır. Bunlar, dönemsel yazma eser formları özelinde incelenmiştir.

Anahtar kelimeler: Midyat, Mor Barsavmo Kilisesi, El Yazması, Süsleme

\begin{abstract}
The city of Midyat which is located in the Tigris part of the South eastern Anatolia Region within the borders of Mardin Province, is an ancient city which has churches and monasteries. The subject of the study is to analyze the Syriac serto calligraphy dated to the $1800 \mathrm{~s}$ in terms of decoration recorded in the archives of Mor Barsavmo Church in Midyat with the number BMCM-00020. As it can be seen in the hagiographic works, this is also a book in which Fanqito tells saints and the miracles of saints and includes poems and hymns. This work is a prayer and hymn book dedicated to St. Mor Dodo, the Metropolitan of Tigrit.

In this study, firstly brief information is given about Mor Barsavmo Church and the methods are explained. In the light of the findings of the research, the ornamental pages of the manuscript written in Syriac have been examined one by one, detailed drawings of each have been made and the text content of the foils with ornaments are summarized. The consecutive geometric decoration compositions in the manuscript are composed of double, triple, quadruple blacks, weaves, and especially crossings. These are analyzed in terms of periodical manuscript forms. As a result of the research, it has been understood that the participants agree on the fact that unauthorized copying is mostly a crime and also a moral issue. However, even though they are teachers and artist candidates in the field of art, the results indicate that they have been copying without authorization. It is also understood from the answers that they do not have enough information about the supervision and criminal responsibility of this illegal act.
\end{abstract}

Keywords: Midyat, Mor Barsavmo Church, Manuscript, Ornament

\section{Giriş}

El yazması; basım tekniğinin gelişmediği dönemlerde, elle yazılmış kitap anlamına gelmektedir. El yazmalarını incelerken öncelikle kitabın tarihsel gelişimine de değinmek gerekmektedir. "Byblos" ( $\beta \hat{\beta} \beta \lambda$ os/ $\beta i ́ \beta \lambda o \varsigma)$ kelimesi, Yunanca'da kitap anlamına gelmekte ve ilk olarak Mısırlıların yazı gereci olarak kullandıkları otsu bitki papirüsün kabuğu ya da lifleri anlamlarını da taşımaktadır. Latince'de ise "liber" kelimesinin ilk anlamı "ağaç kabuğu”, ikinci ve en çok kullanılan anlamı kitaptır. Bunun yanısıra Çinlilerin eski çağlarda olduğu gibi bugün de kitap anlamında kullandıkları yazı karakteri, aynı zamanda ağaç ya da bambu tabletlerini ifade etmek için de kullanılmaktadır (Labarre, 1994, s. 12).

El yazmaları, Antik Çağ'dan bugüne gelen uygarlıklar hakkında bilgi sahibi olmamızı sağlayan tarihi belgeler niteliği taşımaktadır. Avrupa'dan günümüze ulaşan el yazmalarına bakıldığın da genellikle Hıristiyanlığın genel kurallarını ve uygulamalarını içeren dini kitaplar olduğu görülmektedir. Özellikle matbaanın icadından önce çizimleri elle yapılan geniş konu yelpazesine sahip el yazması eserlerde yoğunluk tarih ve din üzerinedir. Osmanlı İmparatorluğu’nda ise sosyal ve kültürel alanlarda yaşanan gelişmeler sanatsal çalışmalara da etki etmiş 
ve her devirde farklı kitap tasarımı ve diğer sanat ürünlerinde üslupların doğmasına katkı sağlamıştır (Odabaş, 2011, s. 145). Her yazma eser bilimsel değerinin yanı sıra, kullanılan yazı karakterleri, süsleme unsurları ve illüstrasyonları ile sanatsal özellikleri ile son derece önemli olmuştur (Kara, 2009, s. 1).

İncelemesi yapılan Suryan el yazması da hem yazı hem süsleme özellikleri bakımından ilgi çekicidir. Eser içerisinde birbirine benzeyen zencerek, zincir, örgü diye tabir edilen birbirlerine benzer kompozisyonlar yer almaktadır. Eserde zencerekler ile oluşturulmuş kapalı kompozisyonlar görülmektedir. Kapalı kompozisyonlar; motiflerin birbirine bağlanarak aynı bütünün parçaları halinde kendi yapılarını tamamlayan kompozisyonlardır. Kapalı kompozisyonlarda, takip edilecek çizgi, belirli bükülmeler ve kırılmalar yaparak başladığı yere döner. Çerçeve halinde uygulandıklarında, köşelerde dönüş yaptıklarından bir 'fasit daire' de oluştururlar (Mülayim, 1983, s. 32). Kapalı formlar içerisinde; zincirleme halkaların devamı şeklinde geometrik hatlardan oluşan tezyini şekillere (motiflere) verilen isim olan zencerekler; üç nokta esasına dayanan ve sonsuzluğu simgeleyen motifler şeklinde yerleştirilmiştir. Tek eksen üzerine gelişen bordürlerin en basit şekillerinden biri geçme zencereklerdir. Zencirek olarak da adlandırılan geçmeler iki kırık doğrunun birbirini kesmesiyle ortaya çıkar. İkiden fazla kırık doğru ile daha girift geçme bordürler ortaya çıkar (Özkeçeci \& Özkeçeci, 2007, s. 97).

Zencerekler ikili, üçlü, dörtlü, beşli, altılı hatlar (şeritler) şeklinde kullanılırlar. Zencereklerde devamlılık esastır ve kesilmeden devam eden akışlar, şeritlerin daima birbirlerini alt ve üstlerinden geçmeleri gibi özellikleri bulunmaktadır (Doğru,1995, s. 2). Eser içerisindeki süsleme kompozisyonlarında zencerekler ile oluşturulmuş (+) artı işareti şeklinde haç motifleri görülmektedir. Prehistorik dönemlerde ateşi yakmada kullanılan iki çubuğun kaynaklık ettiği düşünülen (Avşar, 2010, s. 121) ve iki çizginin düz açı ile kesişmesi sonucu ortaya çıkmış olan bu motif zamanla gamalı haça dönüşerek ateş ve güneşin sembolü olmuştur (Wilson, 1896, s. 765768). İsmini Yunan alfabesindeki gamma(F) harfi ve (+) haç şeklinden alan bu motif dört gamma harfinin ortada birleşmesi ile oluşmaktadır. Aynı motif svastika (Swastika) olarakta adlandırılmaktadır. Svastika kelimesi Sanakritçe'de "su (iyi)" ve "'asti (olmak)" kelimelerinin birleşiminden oluşmuş, "iyi olmak, sağlıklı olmak" anlamlarını taşımaktadır (Gümüştekin, 2011, s. 108). Eserdeki kompozisyonlar içinde yer alan formların bu anlamlara işaret ettiği düşünülmüştür.

\section{Yöntem}

Üzerinde çalışılan Süryanca serto hatla yazılmış yazma eser; üst deri kapak bölümün de görüleceği üzere, Midyat ilinde bulunan Mor Barsavmo Kilisesi arşivinde bulunmakta olup, BMCM-00020 envanter numarasında kayıtlıdır. Çalışmanın materyallerinin elde edilmesi için, basılı ve online literatür ile kitabın kilisede bulunan envanter kayıtları incelenmiş, eser ve içeriği hakkında bilgiler edinilmiş ve doküman analizi yöntemi ile analiz edilmeye çalışılmıştır. Eserin süslemeli kısımlarda yer alan kimi semboller ve konuların içerikleri ile özet tercümeleri ve transkripsiyonları Mardin Artuklu Üniversitesi Süryani Dili ve Edebiyatı öğretim üyesi Doç. Dr. Mehmet Sait Toprak tarafından yapılmıştır. Bunun yanında, yine bazı açıklamalar da Mor Barsavmo Kilisesi eğitmeni Ayhan Gürkan'nın anlatımlarından da faydalanılmıştır. Söz konusu eser, detaylı incelendikten sonra, süslemeli sayfaları tespit edilmiş, bu yazmanın süslemeli varağının genel ve detay içeren fotoğrafları çekilmiştir. Ayrıca değerlendirilmesi yapılacak sayfaların çizimleri de yapılarak desen ve renk analizleri hakkında tespitlerde bulunulmuştur.

\section{Bulgular ve yorum}

\subsection{Midyat ve Mor Barsavmo kilisesi}

Tur 'Abdin'in asli yerleşim yerlerinden olan Midyat, adını M.Ö. 879'da Aşurnasirpal II'nin bir sefer düzenlerken geçtiği yer olan 'Matiāte'den alır. (Takahashi, 2011, s. 291-292). Mardin'den Gozarto'ya (Cizre) doğu-batı ana yol üzerinden coğrafi olarak konumu, doğusunda Dargeçit ilçesi, batısında Ömerli ilçesi, kuzeybatısında Savur ilçesi, kuzeyinde Batman iline bağlı Gercüş ilçesi, güneyinde Nusaybin ilçesi, güney doğusunda ise Şırnak iline bağlı İdil ilçesinde yer almaktadır. Yukarı Mezopotamya'da yer alan ve Süryani Ortodoks Hristiyanlığı'nın merkezi olan Mardin (Marde), ilk asırlardan itibaren Hıristiyanlığı kabul etmiş ve birçok Süryani din adamının yetiştiği bir merkez olmuştur (Takahashi, 2011, s. 81-86).

Midyat; Süryani Kilise geleneği ile Süryani kültür geleneğinin beşiği ve kalbi sayılmaktadır (Bilge, 2001, s. 507). Süryaniler; etnik köken olarak Mezopotamya'da yasayan Semitik ırka, dinsel olarak da Hıristiyanlığa mensup bir topluluktur (Malouf, 1998, s. 64). Süryani Kadim ifadesi; Süryani Kilisesi tarafından kendilerinin ilk Hristiyanlar olduklarının kanıtı olması ve diğer Ortodoks kiliselerden farklılıklarını belirtmek için kullandıkları bir ifade olmuştur (Erginer, 2007, s. 30). Üç farklı görüş bulunan Süryani halkının kökenlerinin birincisi Arami kökenli, ikincisi Asuri kökenli, üçüncüsü de tüm antik Mezopotamya halklarından oluşmuş, Helen uygarlığıyla yoğrulmuş, kan esasına dayanmayan bir kültürel halk olduklarıdır (Durak, 2005, s. 189). Süryani Ortodoks Kilisesi'nin kabul ettiği bir diğer yaklaşıma göre ise, Süryani olarak adlandırılan halkın Sami ırkından olduğu ve Ortadoğu'da Subariler, Sümerler, Akadlar, Babilliler, Asurlular, Kenaniler, Aramiler, Keldaniler, Fenikeliler, Tedmurlular, Abgarlılar gibi devletleri kuranların Süryanilerin ataları olduğu kabul edilmektedir (Akyüz, 2005, s. 16). Midyat merkezde bulunan Mor Barsavmo Kilisesi hakkında çok fazla kaynak olmamasına rağmen 
1760'lara kadar manastır olarak kullanıldı̆̆ 1 bilinmektedir. T.A. Sinclair'e göre XIV. yüzyıl sonları, XV. yüzyıl başlarında inşa edilmiştir. Kilise 1910 ve 1991'de olmak üzere iki kere restore edilmiştir (Palmer, 1990, s. 98, Keser, 2002, s. 77, Koluman, 2001, s. 103). Garip ve dertli insanlara mucizeleriyle derman olan Aziz Mor Barsavmo adı kiliseye adanmıştır. Mor Abrahom’un öğrencisi olan Mor Barsavmo, Malatyalıdır ve birçok mucizelerinin olduğu anlatılmaktadır. Mor Barsavmo Kilisesi, Midyat ve Midyat ilçesinde Diyarbakır Kültür ve Tabiat Varlıklarını Koruma Kurulu tarafindan tescillenen eserler listesinde bulunan yapılar arasında yer almaktadır. Geleneksel biçimde inşa edilmiş kilisede zengin süslemeler bulunmaktadır (İș, 2006, s. 129). Kilisenin mimari plastiği özellikle geometrik formlu süslemeler ile örgüler şeklinde kullanılmıştır. Kilise içerisinde bulunan okul ve misafir odaları kilisenin avlusuna açılmaktadır. Mor Barsavmo Kilisesi'nin taş süslemeleri dönemin ve bölgenin özelliklerini taşımakta olup günümüzde de halen aktif durumdadır. Günlük sabah ve akşam ibadetler yapılarak, kilise eğitmeni Ayhan Gürkan tarafından dua ve ilahiler öğretilmektedir.
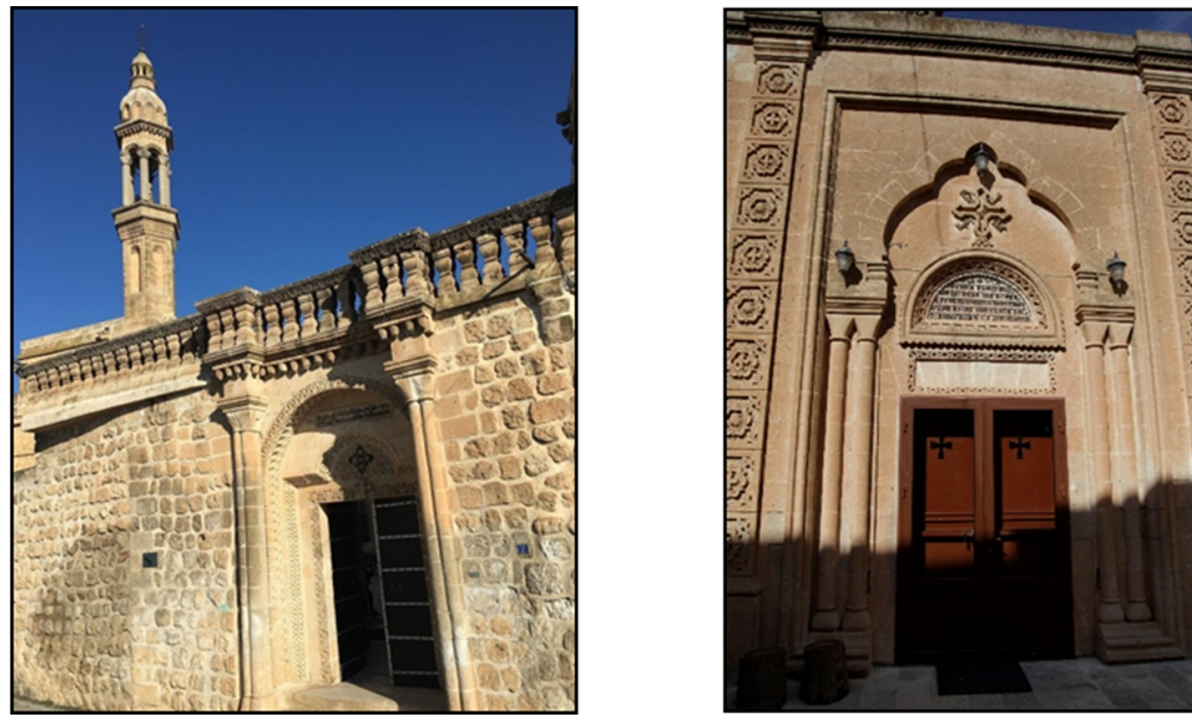

Görsel 1. Mor Barsavmo kilisesi

\subsection{Süryanca el yazmasının süslemeli sayfaları}

Yazı özelliklerinden anlaşıldığına göre yaklaşık olarak 1800'lü yıllara tarihlenebilecek olan Süryanca el yazması; süsleme özellikleri bakımından özensiz çizgilerle fakat kendi içinde sistemli geometrik çizgilerden oluşmaktadır. Genellikle, geometrik çizgilere zencerek denmektedir; tanımına uyan motiflerle, örgüler, geçmeler olarak tanımlanabilen motifler el yazmanın tamamında kullanılmıştır (Keskin \& Zenbilci, 2017, s. 1137-1158).

Tablo 1

Tespit fişi

\begin{tabular}{ll}
\hline Eserin Adı & Azizleri Anma Günü (İlahi Kitabı) \\
\hline Envanter No & BMCM-00020 \\
\hline Müellif & Kayıtlı değil \\
\hline Müzehhib & Kayıtlı değil \\
\hline Konu & İlahi ve dua kitabı \\
\hline İstinsah Tarihi & $1825-$ H.1240/1241 \\
\hline Boyut: & $30 \mathrm{cmx} 20 \mathrm{~cm}$ \\
\hline Sayfa & 498 \\
\hline Yazı Türü: & Süryanca serto hat \\
\hline Cildi & Deri kap, şirazeli \\
\hline Hal-i Hazır Durumu & Cildinde ve sayfalarında yıpranmalar mevcuttur. \\
\hline
\end{tabular}

Görsel 2'de görüldüğü gibi eserin cildi açık kahverengi deri üzerine çizgi demiri ile dört köşesi çerçevelenmiş ve iç uçlarından birleştirilerek dik üçgenler oluşturulmuştur. 

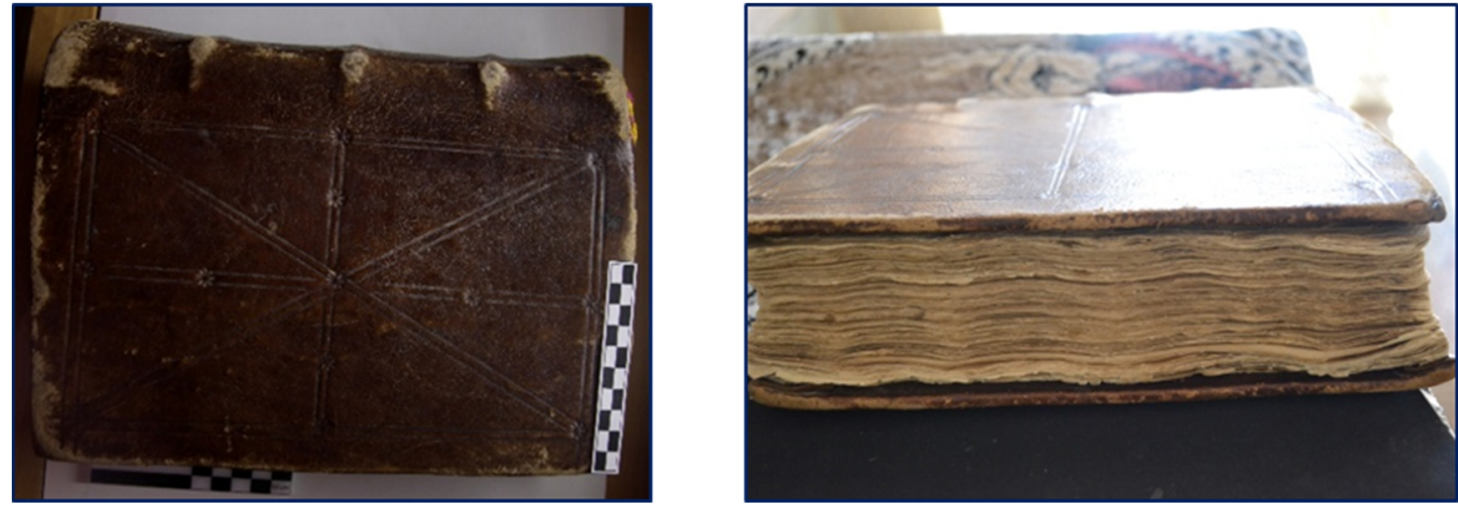

Görsel 2. El yazmasının cildi

Görsel 3'de Kaide üzerine oturtulmuş ve zencerekler ile çevrelenmiş içerisinde küçük geçmelerden oluşturulmuş büyük haç motifi görülmektedir. Karşısındaki sayfada sol elinde yeryüzü hâkimiyetini temsil eden asa ve sağ elinde ise göksel krallı̆̆ı simgeleyen 'haç'ı tutan İsa figürü yer almaktadır.

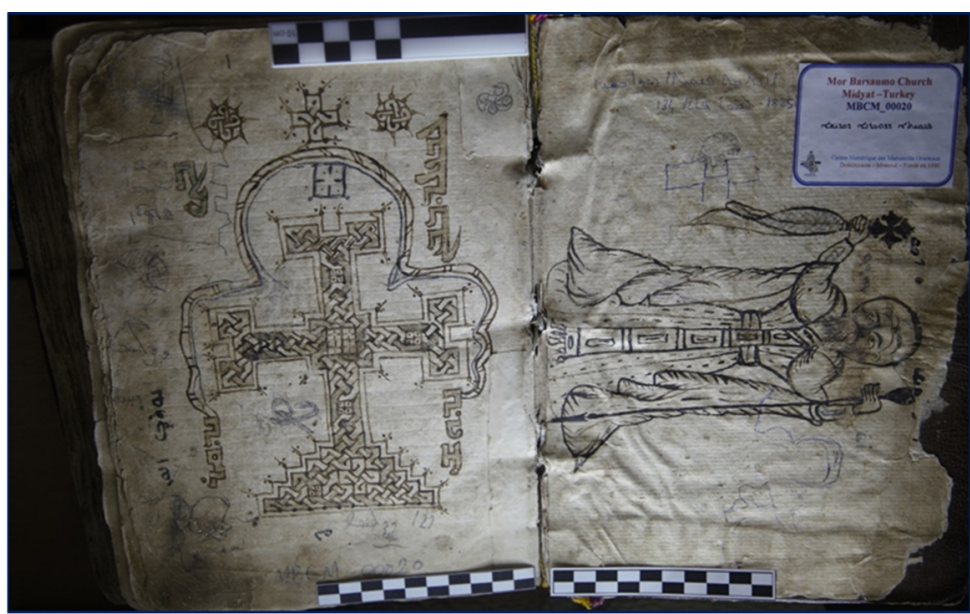

Görsel 3. Kaideli haçı ve İsa minyatürlü süslemeli sayfa

2. sayfada kaide üzerine yükselen 'haç’ın yukarıdan aşağıya doğru sağlı ve sollu olarak estrangelo hat ile şu yazı yer almaktadır: "Bokh ndaqar 1-b’aldbobeyn ndawaş" "Seninle süngüleriz düşmanlarımızı-(ve seninle) ayaklarımızın altında çiğneriz”. Kısaca 'haç'ın etrafına hat olarak sağlı-sollu yukarıdan aşağıya doğru istiflenen yazının açılımına başka kiliselerde rastlamak mümkündür (Görsel 3).

Bu yazının açılmış hali ise şöyledir: "Bokh ndaqar 1-b'aldbobeynu-metul şmokh ndaweş l-soneyn" "Seninle süngüleriz düşmanlarımızı- ve senin adın uğruna hasımlarımızı ayaklarımızın altında çiğneriz". Burada dikkate değer olan şey bu form ve içeriğe sahip yazıların haçın etrafına istif edilmesi son derece ilginç ve ilgi çekicidir. Ayrıca büyük kaideli haçın sağ ve sol üst başlarında geçme ile oluşturulmuş küçük haçlar da görülmektedir.

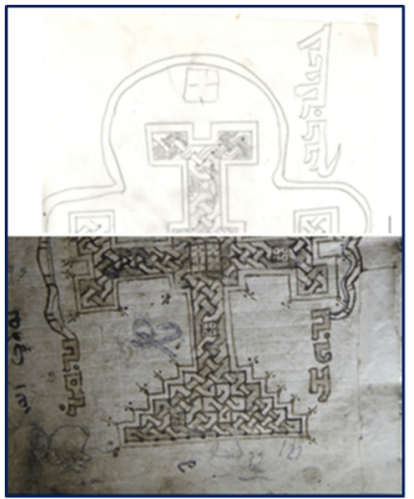

Görsel 4a. Kaideli haç detay çizimi (2.sayfa)

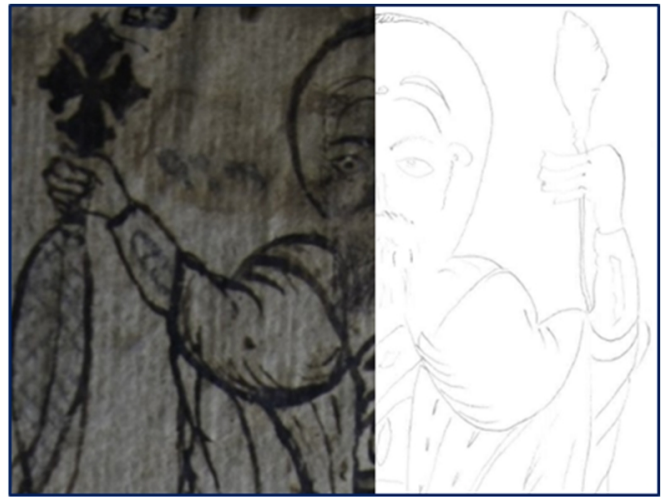

Görsel 4b. İsa figürü detay çizim (1.sayfa) 


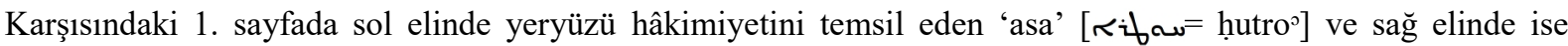
göksel krallığı simgeleyen 'haç'ı tutan İsa figüründe 'kûrsyo’nun yani 'saltanatı/krallığ temsil eden 'taht'ın yer

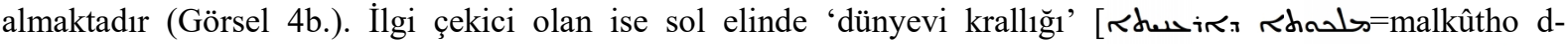
arconoytho] temsil eden 'asa'nın sağ tarafına 'asa'nın Süryanca baş harfi olan 'ḥeth' harfi yani ' <iో w' 'hutro'nun 'ḥeth'i; İsa'nın sağ elinde ise 'haç'ın să̆ tarafında yer alan 'ku' [ح] yani 'kaf' [-n] ve 'waw' [a] baş

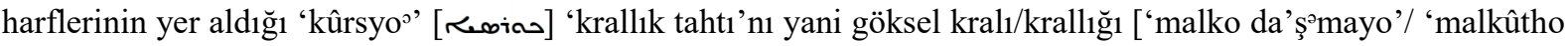
da'şmayono'] temsil etmektedir.

Görsel 5'de Tanrısal güç, destek ve güven üzerine, Kutsal Azizlerin anısına Fanqîtho kitabını yazmaya başladık. Başlangıçta (qadmo'îth țekso ${ }^{\circ}$ d-cal= ilkin/başlangıçta ...-nın hakkında), Tanrı'yla bezenmiş seçilmişler arasından seçilmiş Tigrit Metropoliti Mor Dodo'nun hagiografik anlatısı yer alır. Mor Dodo'nun dualarıyla cüzzamlı bir adamın iyileşmesi anlatılmıştır. Menkibe türünden anlatıların aziz ve azizelerin hayat hikâyelerinde yer verilmesi neredeyse bir uslûp ve form halini almıştır (Harvey, 2011, s. 185-186).

Süryanice yazmaların geleneksel mukaddime kabilinden ser levha olacak şekilde çoğu zaman Estrangelo hattla olsa da bazen burada olduğu gibi Serto ile ve kırmızı mürekkeple, Baba Allah, Oğul İsa ve Kutsal Ruh üçlemesinin ismiyle güç vermeleri dileğiyle başlanır:

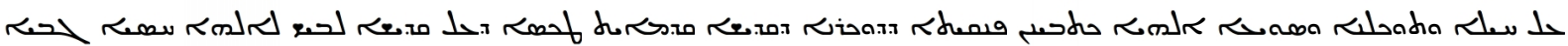

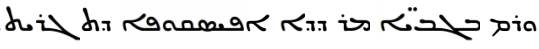

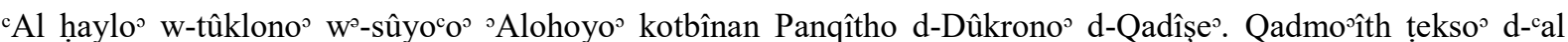

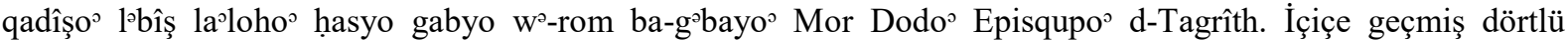
geçmelerle işlenmiş ve yazının üç etrafını çevrelemiş süsleme bir kompozisyon dikkat çekmektedir. Renksiz oluşturulan kompozisyonda sadece orta kesişme yerlerinde hafif siyah gölgelendirmeler yapılmıştır. Ortadaki gölgelendirmeli küçük zencereklerin sağında ve solunda küçük karelerde noktalamalar görülmektedir. Kompozisyonun en üst orta kısmında haç bulunmakta ve kompozisyon bu motifin her iki tarafında simetrik olarak devam etmektedir.
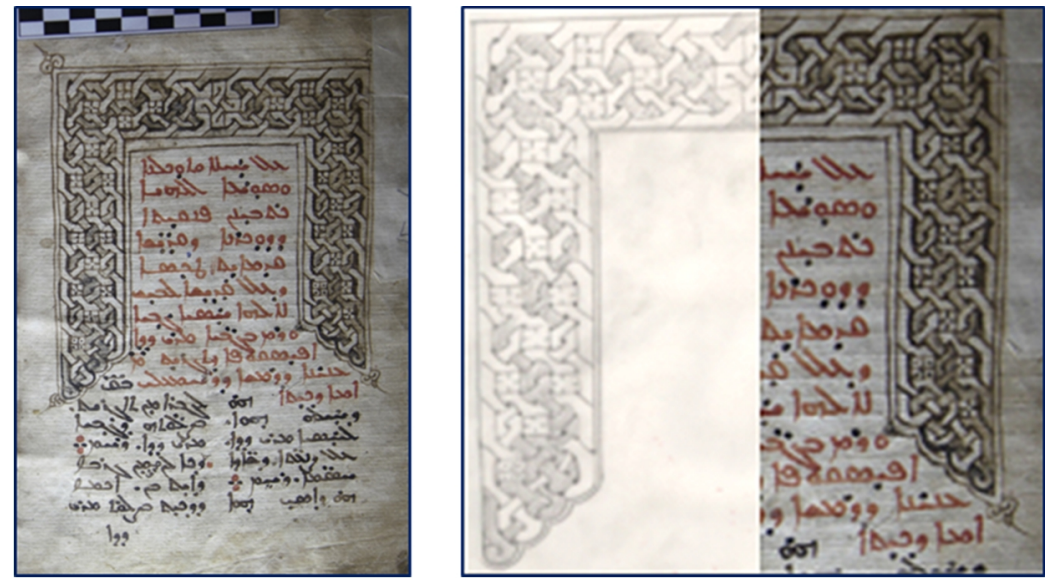

Görsel 5. Süsleme detay çizimi 1

Görsel 6'da Yoldat Aloho yani Theotokos (Tanrı Anası) Meryem'in doğumu, babası Yuyakim ve annesi Hana hakkındaki bölümdür. Burada Meryem Ana'nın doğumu, doğumuyla insanların beklediği kurtarıcının kurtuluş planının gerçekleşmesi, ihtiyar anne babanın yaşlıyken aldıkları müjdeyi, yeryüzünün Meryem Ana'nın doğumuyla bereketlenmesi, onların kurtuluş kapısı olması ve bereketlenmeleri için dua dilekleri anlatılmıştır. Tekso $^{\circ}$ d-cal Mawlodoh d-Yoldath ${ }^{\circ}$ Aloho $^{\circ}$ Maryam wº-dûkronoh d-Aboheyh Yûyaqîm w’-Hano ${ }^{\circ}$. Süsleme olarak; dikdörtgen kartuş, ikiye bölünmüş ve karşılıklı simetri oluşturulmuştur. Dikdörtgen form içinde oluşturulan desen, bir ilahinin bitip diğerin başladığı bölümde yer almıştır. Dikdörtgen çerçevenin dört ucu köşeliklerle bağlanmıştır. Kırmızı zemin üzerine siyah mürekkeple çizilmiş desenin merkezinde geçme ile oluşturulmuş artı işareti formu görülmektedir. 

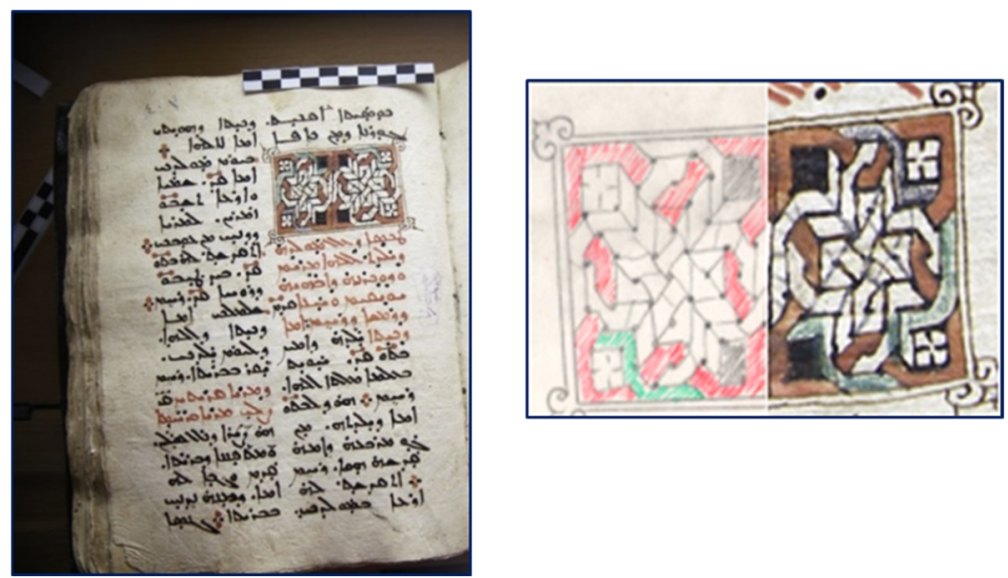

Görsel 6. Süsleme detay çizimi 2

Görsel 7'de Mecdelli Meryem Bölümü bulunmaktadır. Ferisi Simon, evinde İsa Mesih'in önünde ağlayıp tövbe ettiğini ve İsa'nın tövbesini kabul edip günahlarını bağışladığı anlatılmaktadır. Aynı zamanda anma bölümünde; Mesih’ten günahlarının bağışlanmasını, yeryüzüne barış esenlik getirmesini dilerler. Süslemesinde dikdörtgen form içinde zencereklerle birbirine bağlanmış kompozisyon ve iki artı işareti göze çarpmaktadır. Beyaz zemin üzerine içilen desen en dış kenardan birer atlamalı şekilde kırmızı ile boyanmıştır. Dikdörtgen form köşegenler ile sonlandırılmıştır.
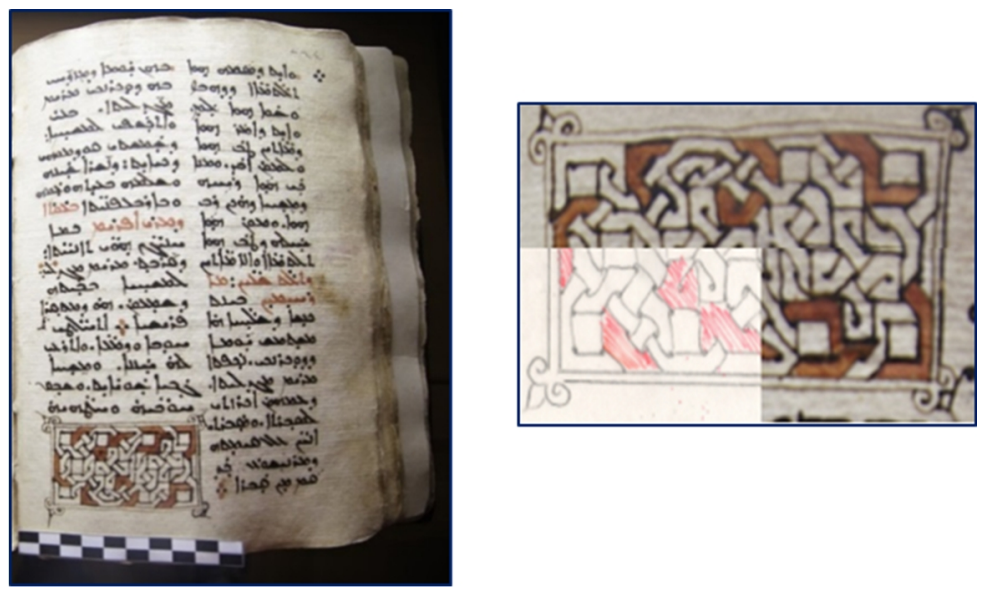

Görsel 7. Süsleme detay çizimi 3

Görsel 8'de Aziz Mor Dimet'in bölümü görülmektedir. Tanrıdan Mor Dimet'in dualarıyla onlara yardım etmesini dilerler. Mor Dimet'in asker iken tanrının onu nasıl hidayetler ile kendi yoluna çektiğini ve geçirdiği ruhsal değişimini anlatıyor. Süslemesinde daha net çizgiler ile çizilmiş dikdörtgen form içerisinde zencerekler ile oluşturulmuş bir kompozisyon ve bu kompozisyonun merkezinde yan yana oluşturulmuş iki artı işareti görülmektedir.
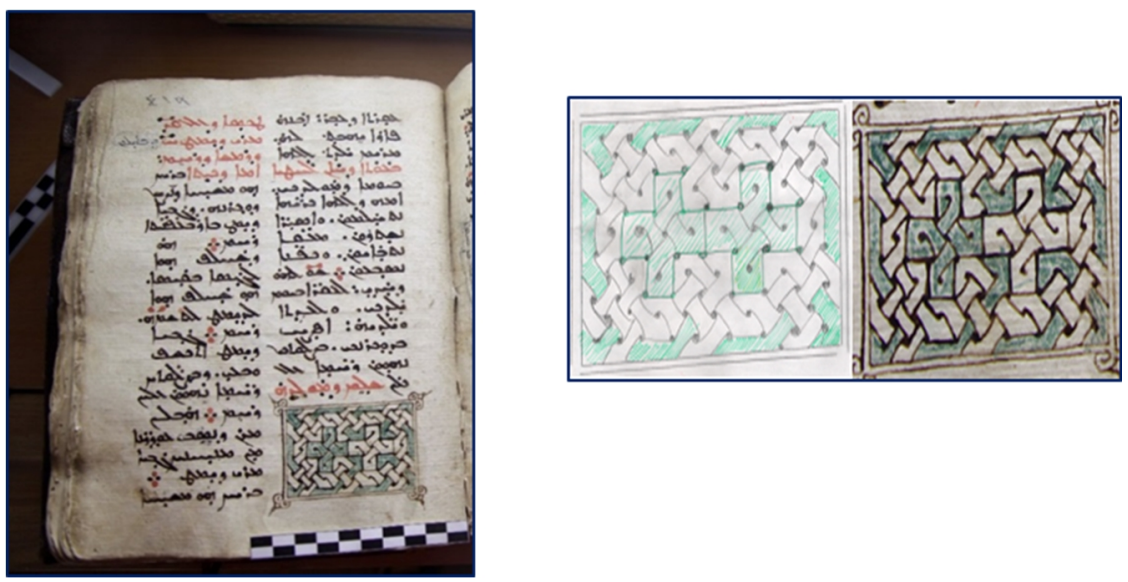

Görsel 8. Süsleme detay çizimi 4 
Görsel 9'da Rab İsa'nın dostu Aziz Mor Dimet'in bahsi geçmektedir. Kutsal Üçleme tarafından sevilen duası ile bize yardımcı, şefaatçi ol ki Rab bize merhamet etsin! diye başlayan litürjiler bulunmaktadır. Süslemede zencerek kompozisyonu kare forma yakın dikdörtgen bir çerçeve içine alınmıştır. Kapalı kompozisyon oluşturan ve birbirine tutturulmuş iki aynı biçimdeki zencerek kompozisyon kendi içinde simetri oluşturmuştur.
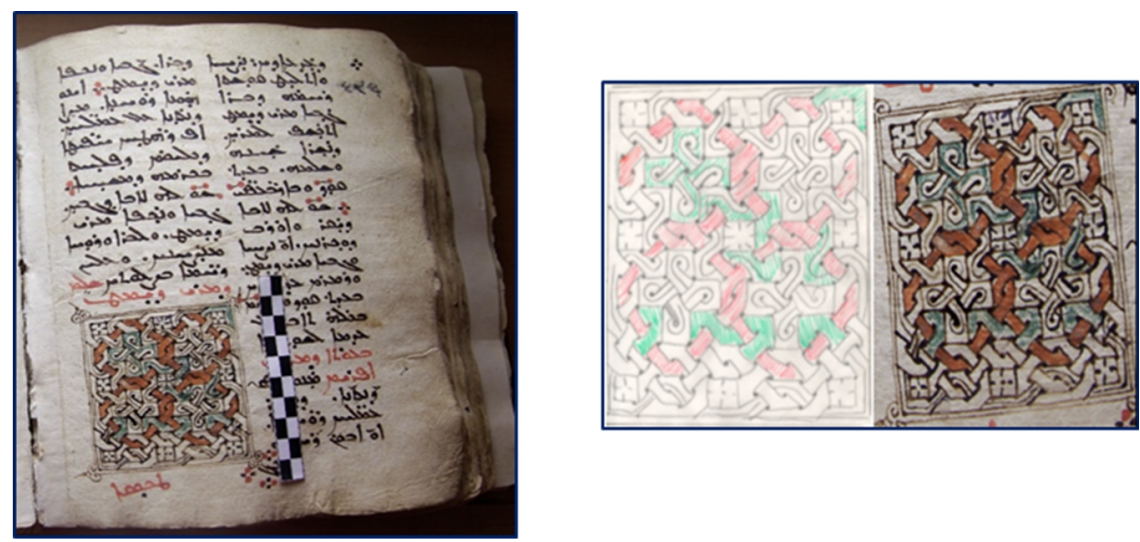

Görsel 9. Süsleme detay çizimi 5

Görsel 10'da Vaftizci Yahya'nın kafasının kesilmesi ve Mor Yuhanon Tayoyo (Arap) Hakkındaki Bölümü bulunmaktadır. Süsleme'de Kompozisyonun bütününde dikdörtgen bir çerçeve içinde merkezde dikdörtgen geniş zincir etrafında küçük kare boşluklar oluşturacak şekilde zincir geçmeler bulunmaktadır. Kırmızı, siyah ve sarı renkler ile zincir detaylar birbirlerinden ayrılmışlardır. Dikdörtgen çerçevenin sol ve sağ üst ve alt köşe kenarları tepelik tabir edilen motifler ile sonlandırılmıștır.
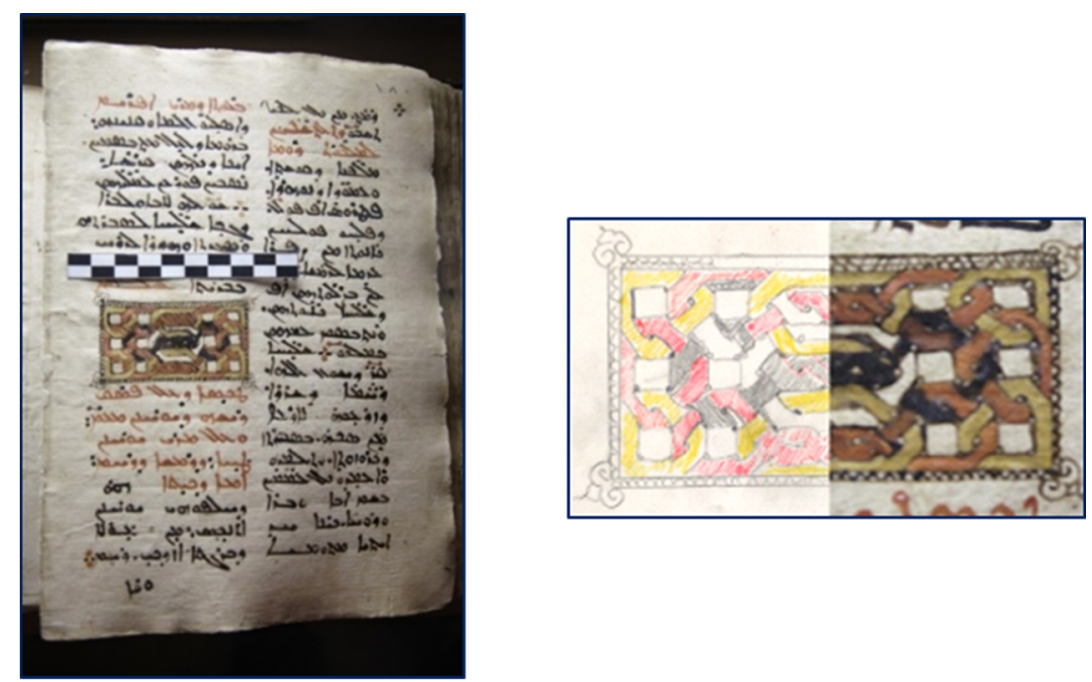

Görsel 10. Süsleme detay çizimi 6

Görsel 11'de ise Mor Yakup'un gemisi cennetin hayat gemisine yetişti. Mor Yakup Kutsal ruh'a temiz mekân oldu. Kutsal kemiklerinde barınıyor. Mor Yakup’un üzerine tüm bilgeler yazmaya kalksa güzelliklerini anlatamazlar. Tanrıya övgüler olsun sevgisiyle seni seçti oğul'a secdeler. Kırmızı Başlıkta ise, Makkabi şehitleri Şmuni, oğulları, ögrretmenler Eli Azar ve Mor Rabil Bölümüdür. Bayan Şmuni ve yedi oğulları ve öğretmenleri Eli Azar'ın çeşitli işkencelerle şehit edilmelerinin ve imanlarını korudukları anlatılmaktadır. Süslemesinde dikdörtgen form içinde simetrik içiçe geçmeler görülmektedir. Simetrik yerleştirilmiş geçmeler birer atlamalı şekilde kırmızı ve siyah olarak renklendirilmiştir. Köşelerde tepelik tabir edilen köşeliklerle sonlandırılmıştır. 

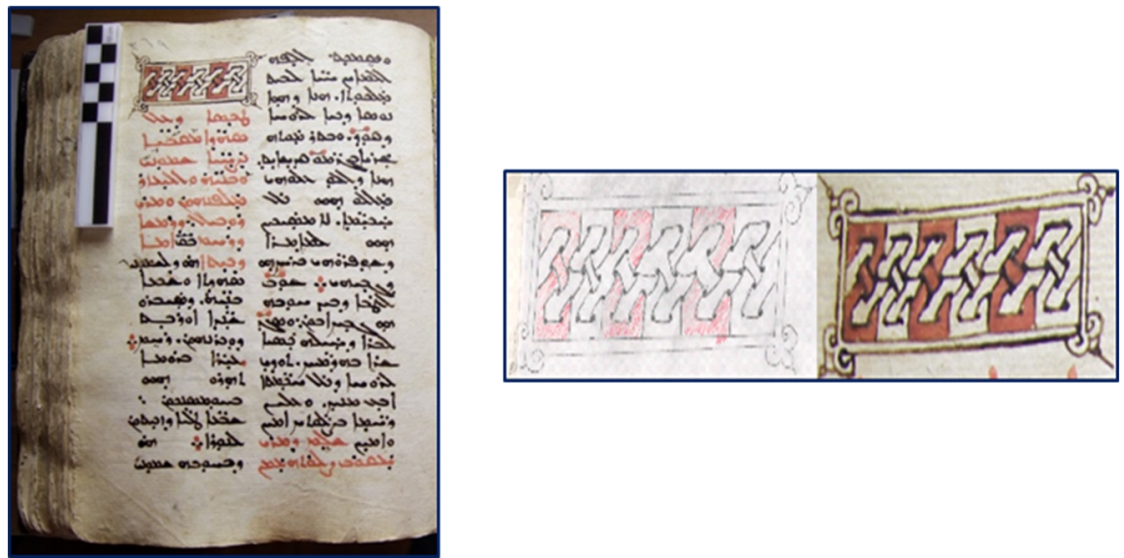

Görsel 11. Süsleme detay çizimi 7

Görsel 12'de Mor İzozoel bölüm bitişi ve çile çekenlerin başı Mor Barsavmo'nun anma günü bölümü yer almaktadır. Süslemesinde ayraç olarak sayfadaki yerini alan ve kapalı bir kompozisyon oluşturan ikili örgü motifi, siyah ve beyaz olarak renklendirilmiştir. Bu örnekte örgü motifi sayfanın sağ ortasında, düz bir şerit halinde kapalı kompozisyon oluşturmaktadır.
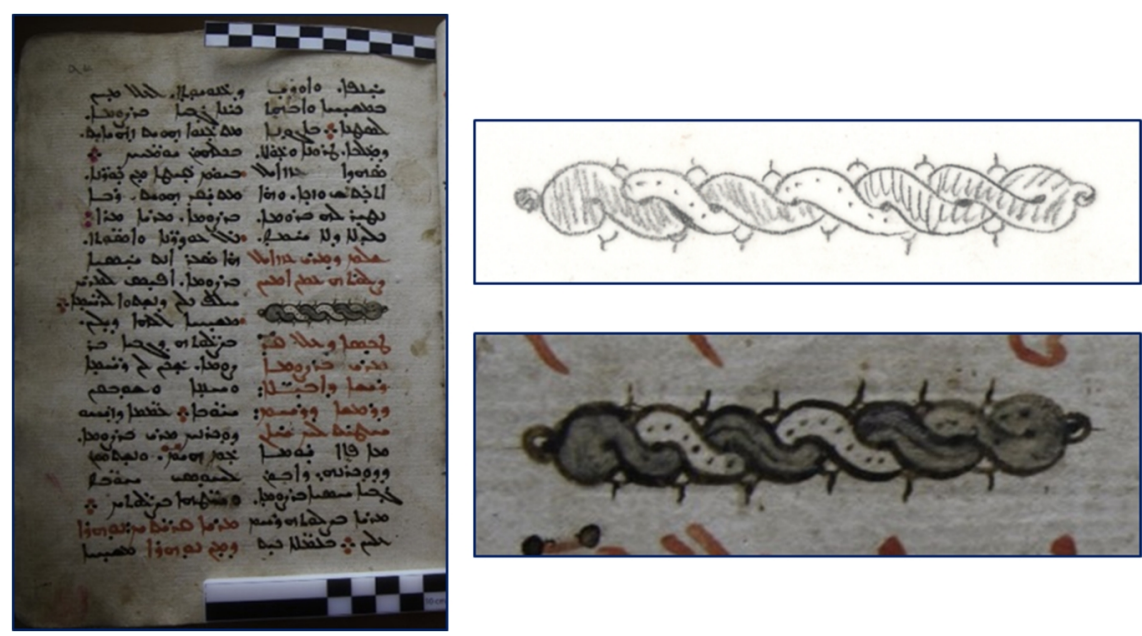

Görsel 12. Süsleme detay çizimi 8

\section{Sonuç}

Midyat Mor Barsavmo Kilisesi ndeki BMCM-00020 envanter numaralı Süryanca serto hatla yazılmış el yazmasının süsleme açısından değerlendirilmesi adlı çalışmada, eserde bulunan süslemeli sayfalar incelenmiş olup, motif, desen ve üslûp özellikleri bakımından değerlendirilmiş ve şu sonuçlara ulaşılmıştır.

Eserde incelenen süslemeli sayfalar gerek motif, desen, gerekse üslûp özellikleriyle çok özenilmiş tarzda olmasa da kendi içinde bir bütünlük oluşturmaktadır. Eserin genelinde aynı form ve tarz da süslemeler bulunmakta olup, içlerinden ayıklamalar yapılarak detay incelemeleri yapılmıştır. Genel olarak çizilen motiflerde iki farklı çizgi kalitesinin görülmesi, eserin farklı kişiler tarafından çizildiği görüşünü oluşturmakla birlikte bunun doğruluğuna dair herhangi bir bilgiye ulaşılmamıştır. Eserin yazıldığ 1 18. Yüzyıl barok ve rokokoya geçiş dönemi ve artık geometrik yerine bitkiselin yoğunluk kazandığı dönem olmakla birlikte; desen özellikleri bakımından Bizans'a (eski’ye) yeni bir öykünme denebilir. Çünkü eserin süslemelerin de bitkisel motiflere ya da Barok Rokoko uslubunda bir kompozisyona rastlanılmamıştır. Anadolu Selçuklu 'da kullanılan geometrik geçme ve zencerekler önce Doğu Roma'da - (Bizans) kullanılmış; sonra aynı topraklara gelen Selçuklular bunu kullanmış ve Batı Roma'da örneklerinin olması da muhtemeldir diye düşünülmüştür. Örneklerin geneline zencerek ve örgülerle oluşturulmuş dikdörtgen formlar hakimdir (Keskin \& Zenbilci, 2017, s. 1138). Dünyanın en eski motiflerinden olan zencerekler, hasır örgüsü gibi bir alttan bir üstten birbirinİ kateden şeritlerden oluşmuştur. Anadolu'da iki veya üç şeritin birbirine değişik şekilde böldüğü örneklere çok fazla rastlanmıştır. Çizgi, nokta ve yaylardan oluşan bir kavram olarak kullanılmıştır (Doğru, 1995, s. 2).

Eserde birbirini tekrar eden basit örgü kompozisyonları da kullanılmıştır. Birbirine dolanan şeritlerden veya iplerden oluşan ikili, üçlü, dörtlü düzenlemeler bulunmaktadır. Bunlar arasındaki en basit ve tipik olanı "ikili örgü" motifidir. İkili örgü motifinin düz bir şerit veya bordür halinde kullanıldığı örnek vardır. Örgü 
kompozisyonlarında, örgüyü oluşturan şeritlerin aynı hareketi tekrar ederek ilerlemesi, adeta sonsuzluk hissi uyandırmıştır. Genel olarak kompozisyonlar simetriktir. Genellikle dikdörtgen form içinde oluşturulan kompozisyonlar köşelikler ile birleştirilmiştir. Küçük tepelik diye tabir ettiğimiz köşelikler hemen hemen hepsinde kullanılmıştır. Yazma eserde kullanılan renkler ise küçük süsleme kompozisyonlarında görülmektedir. $\mathrm{Bu}$ süsleme kompozisyonlarında genellikle siyah mürekkep ile çizilmiş ise de zaman zaman motiflerin zemininde sulandırılmış kırmızı ve açık yeşil renkler kullanılmıştır. Eserin genelinde çok fazla renk değişiklikleri görülmemektedir. Eserde görülen zencerek kompozisyonlar genellikle birbirini takip eden simetrik ya da birbirine çok benzeyen formlardadır. Bazı örneklerde geometrik formun etrafinda birbirini takip eden örgüler oluşturan karmaşı kompozisyonlarda kurulmuştur. Bu kompozisyonlar; tezhipli eserlerde bab başı, fasıl başı olarak adlandırılan üslupta kullanılmış ve kitap içerisinde yer alan aziz ve azizelerin bahsi geçtiğinde yeni bir kompozisyon oluşturulmuştur. Geometrik paftalar, birbirini takip eden basit örgüler şeklinde olduğu gibi birbirine dolanan geçmelerden oluşan ikili, üçlü, dörtlü düzenlemeler kullanılmıştır. Zencerekler, bazı örneklerde klasik tarzda bazı örneklerde ise tamamen firça darbeleriyle, basit şekillerde iki ve üç iplik biçimde uygulanmıştır. (Alav, 2011, s. 22). Dikdörtgen form içinde zencereklerle oluşturulan kompozisyonların içerisinde ateşi ve gücü simgeleyen haç simgelerinde kullanılmıştır.

\section{Kaynakça}

Akyüz, G. (2005). Tüm yönleriyle Süryaniler. Mardin: Mardin Anadolu Ofset Yayınc1lı.

Alav, Z. (2011). Antalya müzesi'nde yer alan el yazması Kur-an'ı Kerimlerin süsleme özellikleri (Yüksek Lisans Tezi). Süleyman Demirel Üniversitesi, Isparta. Yök tez veri tabanından erişildi (Tez no: 287906).

Avşar, L. (2010). Antik Yunan seramiklerdeki haç ve çarkıfelek simgeleri ve bunların Avrasya, Anadolu ve Mezopotamya kültürlerindeki muhtemel kaynakları. Mukaddime: Mardin Artuklu Üniversitesi Sosyal Bilimler Enstitüsü Dergisi, 4(11), 115-141.

Bilge, Y. (2001). Geçmişten günümüze Süryaniler. İstanbul: Zvi-Geyik Yayınları.

Doğru, M. H. (1995). Selçuklulardan yirminci yüzyıla kadar tezhipte, ciltte ve mimaride kullanılmıș zencerekler üzerine motiflerin kökenlerine ilişkin bir araştırma (Sanatta Yeterlik Tezi). Mimar Sinan Güzel Sanatlar Üniversitesi, İstanbul. Yök tez veri tabanından erişildi (Tez no: 42366).

Durak, N. (2005). (Süryani Ortodoks kilisesi) Süryaniler ve Süryanilik Cilt 1. Ankara: Orient Yayınları.

Erginer, G. (2007). Etno-kültürel sinırlar Tur Abdin Süryanileri örneğinde. Ankara: Ankara Üniversitesi Bilimsel Araştırma Projesi Kesin Raporu, Ankara Üniversitesi Bilimsel Araştırma Projeleri.

Gümüştekin, N. (2011). Anadolu ve diğer kültürlerde işaret ve simgelerde anlam. Balıkesir Üniversitesi Sosyal Bilimler Dergisi, 14(11), 103-117.

Harvey, S. A. (2011). "Hagiography", The Gorgias encyclopedic dictionary of the Syriac heritage. Piscataway, NJ: Gorgias Press.

İş, A.V. (2006). Dinler ve diller kenti Midyat. İstanbul: Nadir Kitap.

Kara, N. (2009). Türkiye'de yazma eser kataloglama çalışmaları: Türkiye yazmaları toplu kataloğu projesi (Tüyatok) örneği (Uzmanlı Tezi). T.C. Kültür ve Turizm Bakanlığı Kütüphaneler ve Yayımlar Genel Müdürlüğü, Ankara.

Keser, E. (2002). Tur Abdin Süryani Ortodoks mimarisi. İstanbul: Ekonomik ve Toplumsal Tarih Vakfi.

Keskin, E., \& Zenbilci, İ. K. (2017). Ortaçağ'da Bizans El Yazmalarında Görülen Örgü Kompozisyonları. Hitit Üniversitesi Sosyal Bilimler Enstitüsü Dergisi, 10(2), 1137-1158. doi: https://doi.org/10.17218/hititsosbil.332586

Koluman, A. (2001). Ortodoğu'da Süryanilik. Ankara: ASAM Yayıncılık.

Labarre, A. (1994). Kitabın tarihi. İstanbul: İletişim Yayınları.

Malouf, A. (1998). Arapların gözüyle Haçlı Seferleri. İstanbul: Telos Yayınları.

Mülayim, S. (1983). Türk süsleme sanatında Arabesk problemi. Arkeoloji-Sanat Tarihi Dergisi, 2(2), 62-85.

Odabaş, H. (2011). Osmanlı yazma esreleri ve Türkiye'de yazma eser kütüphaneciliği. Bilig, 56, 143-164. Erişim adresi: http://hdl.handle.net/10760/19238

Özkeçeci, İ., \& Özkeçeci, B. Ş. (2007). Türk sanatında tezhip. İstanbul: Seçil Ofset Yayıncılık. 
Palmer, A. N. (1990). Monk and Mason on the Tigris Frontier: the early history of Tur 'Abdin. Cambridge University Press.

Takahashi, H. (2011). "Midyat/Matiate”, The Gorgias encyclopedic dictionary of the Syriac heritage. Piscataway, NJ: Gorgias Press.

Wilson, T. (1896). The Swastika, the earliest known symbol, and its migration. USA, Washington: D.C Press.

Görsel Kaynakçası

Görsellerin tümü araştırmacı tarafından çekilmiş ve Betül Coşkun Çelik şahsi arşivine aittir. 